\title{
Gerontology course in the nursing undergraduate curricula
}

\author{
CURSO DE GERONTOLOGIA NOS CURRÍCULOS DE GRADUAÇÃO EM ENFERMAGEM \\ CURSO DE GERONTOLOGÍA EN LOS CURRÍCULOS DE GRADO DE ENFERMERÍA
}

\author{
Samira AISenany ${ }^{1}$, Amer A. AISaif ${ }^{2}$
}

\begin{abstract}
Objective: To explores nursing faculty members' attitudes towards older people, their thoughts about gerontological nursing education. Method: Five focus groups and a survey were used with nursing faculty members 132 at the three nursing schools to explore their attitudes towards the care of older people and the perceived status of gerontological nursing education. The survey was given to 132 faculty members, including 76 clinical instructors, 40 associate professors and 16 professors. The nursing faculty in general had a positive attitude toward older people $(M=3.36$, SD 0.25), and teachers' attitudes were higher than those of their nursing students ( $M=3.18$, SD0.29). Results: This study results suggests that Saudi nursing curricula should include more extensive gerontology content and clinical experience with older people. Conclusion: This is the first time in Saudi Arabia that research has listened to their voices and examined their commitments toward gerontology education.
\end{abstract}

\section{DESCRIPTORS}

Education, nursing

Geriatric nursing

Geriatrics

Curriculum

Clinical competence

Faculty, nursing

\section{RESUMO}

Objetivo: Explorar a atitude dos docentes de enfermagem em relação às pessoas mais velhas e suas reflexões sobre o ensino de enfermagem gerontológica nos currículos de graduação em enfermagem na Arábia Saudita. Método: Uma pesquisa com cinco grupos focais foi utilizada com membros do corpo docente, nas três escolas de enfermagem. O levantamento contou com 132 membros, incluindo 76 instrutores clínicos, 40 professores associados e 16 professores. A faculdade de enfermagem em geral teve uma atitude positiva para com os idosos ( $M=3,36$, DP 0,25 ) e as atitudes dos professores foram mais elevadas do que os de seus alunos de enfermagem $(\mathrm{M}=3,18$, SD0.29). Resultados: Sugerem que os currículos de enfermagem Sauditas devem incluir um conteúdo mais extenso em gerontologia e experiência clínica com as pessoas mais velhas. Conclusão: Esta foi a primeira vez na Arábia Saudita, que a pesquisa ouviu suas vozes e examinou os seus compromissos para com a educação gerontológica.

\section{DESCRITORES \\ Educação em enfermagem \\ Enfermagem geriátrica \\ Geriatria \\ Currículo \\ Competência clínica \\ Docentes de enfermagem}

\section{RESUMEN}

Objetivo: Explorar la actitud de los docentes de enfermería con relación a las personas mayores y sus reflexiones acerca de la enseñanza de enfermería gerontológica en los currículos de grado de enfermería en Arabia Saudita. Método: Una investigación con cinco grupos focales fue utilizada con miembros del cuerpo docente, en las tres escuelas de enfermería. El relevamiento contó con 132 miembros, incluyéndose a 76 instructores clínicos, 40 profesores asociados y 16 profesores. La facultad de enfermería, en general, tuvo una actitud positiva ante los ancianos ( $M=3,36$, DP 0,25 ) y las actitudes de los profesores fueron más elevadas que las de sus alumnos de enfermería ( $M=3,18$, SD0.29). Resultados: Sugieren que los currículos de enfermería sauditas deban incluir un contenido más extensivo en gerontología y experiencia clínica con las personas mayores. Conclusión: Esta fue la primera vez que la investigación oyó las voces de Arabia Saudita y examinó sus compromisos con relación a la educación gerontológica.

\section{DESCRIPTORES}

Educación en enfermería

Enfermería geriátrica

Geriatría

Curriculum

Competencia clínica

Docentes de enfermería

\footnotetext{
${ }^{1}$ Assistant Professor, King Abdulaziz University, Department of Public Heath, Faculty of Nursing, Jeddah, Saudi Arabia. ${ }^{2}$ Assistant Professor, King Abdulaziz University, Department of Physical Therapy, Faculty of Applied Medical Sciences, Jeddah, Saudi Arabia

$\begin{aligned} & \begin{array}{r}\text { Rev Esc Enferm USP } \\ 2014 ; \text { 48(6):1077-84 } \\ \text { www.ee.usp.br/reeusp/ }\end{array} \text { Received: 07/02/2014 } \\ & \text { Approved: 09/04/2014 }\end{aligned}$
}




\section{INTRODUCTION}

Globally, the ageing population is currently one of the main issues facing international health care systems. It is a recognized fact that with advancing age, the likelihood of developing health problems and chronic disease will increase, and the demand for health care resources will rise. On the other hand, in Eastern countries such as Saudi Arabia the previous research is limited and has not examined professionals' attitudes and intentions toward the care of older people, with a focus on factors such as personal, educational, or clinical experiences that positively or negatively influence attitudes and intentions.

In Saudi Arabia culture, older people are regarded with great admiration and respect: for example, it is customary for everyone to stand up when they enter a room, they are allocated the best seats and they are offered drinks and food before anyone else. They are addressed in soft voices and are not called by their first names, but instead are referred to as the father or mother of the oldest son (even if they have a daughter who is older than their son). Young people are expected to be polite and restrained, and even avoid smoking cigarettes or chewing gum when older people are present. In the home environment, an older person's views usually prevail.

The development, implementation and evaluation of appropriate interventions and continuing education programs to increase students' nursing knowledge and improve attitudes in gerontology nursing, is an important issue in Saudi Arabia. Many authors have contended that the method by which gerontological content is currently presented is problematic. For example, courses on ageing tend to be loaded with pathology- and disease-oriented content and contain little to no instruction about the normal physical, psychological and social ageing process ${ }^{(1-2)}$.

Another study was examined the attitudes of 47 staff at an older people's care facility after gerontology education over a 12-month period. The study found that staff members who attended the education sessions showed more positive attitudes toward older people $e^{(3)}$. Similarly, one study points out the importance of continued evaluation of nursing curricula and evidencebased teaching-learning strategies, which should be integrated into the Bachelor of Science in Nursing curriculum in relation to older people. The study evaluated effective teaching strategies, comparing lecture-discussion techniques with simulation in terms of their ability to change nursing students' attitudes toward older people. In addition, the independent variables of age and previous contact with older people were examined. The study was implemented to explore the potential for a four-week curriculum module in gerontological social work education to positively impact students' practicerelated knowledge of ageing, as well as their attitudes toward older people and their interest in working with them. The study revealed a significant increase in students' knowledge of ageing ${ }^{(4)}$.

We tried different types of educational interventions to improve students' attitudes toward older people and increase their likelihood of selecting a career in care of older people. Examples of these interventions include regular courses on ageing, clinical practice that leads to contact by students with older people, a combination of theory and clinical intervention, and special teaching techniques. The study used a quasi-experiment design in two different universities for nursing students on a baccalaureate program ${ }^{(5-6)}$.

Many studies have examined various types of education program to influence attitudes and knowledge. There is those that use multimedia to motivate students to select careers in care for the ageing with stressed in the importance of good mentor support during placements to help students achieve learning that goes beyond their learning objectives ${ }^{(7-12)}$. Clearly nursing students need role models in their education and practice settings, such as nursing educators who are dedicated to the older population. As well as clinical mentors nursing educators in nursing colleges can play a major role in changing students' knowledge and attitudes using the gerontology course programme to encourage positive attitudes and foster willingness to work with older people and their families. In order to strengthen the gerontological curriculum in nursing, the faculty involvement and enthusiasm must come first in interesting nurses in caring for older people. One study noted that planned faculty development activities, especially those that lead to gerontological nursing credentials, have a positive change in suggestion toward presenting a clinical rotation in care services for older people as part of the associate degree nursing curriculum ${ }^{(13)}$.

Also, the literature highlights that experience of clinical placements with older people in nursing homes can be an ambivalent one, producing both positive and negative views, and that this can influence nursing students' career options with regard to older people. There is some evidence that gerontology nursing education can foster positive attitudes and increase students' knowledge about work with older people. However, the studies also shed light on the fact that gerontology nursing curricula need to develop planned teaching strategies for the care of older people, such as using evidence-based teaching and learning to promote more knowledge of ageing and to foster positive attitudes.

Previous studies have stressed the need for nursing education to focus on community settings with well older people rather than excluding ill older people, and argue that this may have a more pronounced effect in fostering favourable attitudes. It is also suggested that special considerations should be given to the knowledge and attitudes of nursing educators with emphasis on the importance of gerontological nursing education in nursing curricula, with 
the focus on changing the attitudes of nursing students to gaining positive knowledge and clinical experiences in gerontological care. All of the above appear essential if students are to choose gerontological nursing ${ }^{(14-18)}$.

In Saudi Arabia, nursing education programs were developed to provide the knowledge, skills, attitudes and value of the role for those who have chosen to work in the nursing profession. With the continuous improvement and upgrading of nursing education and nursing practices, graduate education programs in nursing have been developed in Arabia. The Universities welcome applications from female Nationals with the personal qualities, intelligence and motivation essential for the study of nursing in a university. Currently in Saudi Arabia c there is no research exploring whether or not clinical placements within educational programs are preparing students for gerontological nursing, and in particular, no assessment of whether or not educational endeavors are fostering an increased willingness in baccalaureate nursing students to work with the ageing population. Nor is there enough current research assessing educational effectiveness in equipping graduates with the skills needed to meet the needs of older people. Consequently, the main goal of this study is to explores nursing faculty members' attitudes towards older people, their thoughts about gerontologic nursing education.

\section{METHOD}

Five focus groups and a survey were used with nursing faculty members at the three nursing schools to explore their attitudes towards the care of older people and the perceived status of gerontological nursing education in the undergraduate nursing curricula in Saudi Arabia. The quantitative-qualitative debate has been, to some extent, about the feasibility, benefits, limitations and implications of combining more than one method in the same study. They emphasize that a mixed-methods approach can produce unique knowledge without the limits that would arise if using qualitative and quantitative approaches independently. In this study, a combination of methods can give a fuller and more accurate picture of gerontology education at nursing schools and elaborate on the focus of care of older people. The mixed method approach in this study seeks complementarity between quantitative data, primarily data from the survey, and qualitative data from the survey and the focus groups discussions in order to provide illustrations and clarifications that lead to a better understanding of the care of older people from the perspectives of nursing teachers. Significantly, a mixed-methods study enabled me to address the many components of this study.

The survey was given to 132 faculty members, including 76 clinical instructors, 40 associate professors and 16 professors before the focus groups. The sample population was obtained from three schools of nursing no restrictions regarding age or previous experiences with older people prevented subjects from participating in the study. I invited all eligible nursing faculty members from the three nursing education programs to participate in this study. Undergraduate faculty was included in the sampling because several researchers have found that students' attitudes toward older people reflect the attitudes of their teachers. In addition, descriptive data about the educational preparation of the faculty and their experiences in teaching gerontological nursing were though important to the understanding of the students' educational experiences with older people. Faculty was included in the study sample only if they had a direct teaching role with undergraduate students. Sampling is an important step in the research process. In quantitative studies in particular, sampling inadequacies can seriously compromise the findings. This was a voluntary convenience sample. I considered several tools before deciding to use Kogan's (1961) Attitudes Towards Old People Scale to measure the attitudes toward older people. The scale measures the affective attitude component towards old people and consists of 16 matched positive-negative paired items with five response categories for each item, ranging from strongly agree to strongly disagree and the negative statements are coded in the reverse. Additionally, the ATOP scale has been found to have acceptable psychometric properties. We also elected to use a modified version of the ATOP scale, as it is considered to take account of the culture. The measure was scored using a Likert scale. Significantly, odd-even reliability, using the Spearman-Brown prophecy formula, was tested in three separate studies and achieved reliability coefficients of $0.76,0.73$ and 0.83 for the Old Person Negative Scale. For the Old Person Positive Scale, the results were $0.77,0.66$ and 0.73 . Inter correlation of positive and negative scales ranged from 0.46 to 0.52 . Significantly, in this study, the reliability of the scales was also checked using an indicator of internal consistency, namely Cronbach's alpha coefficient, a model of internal consistency, based on the average inter-item correlation. Ideally, the Cronbach alpha coefficient of the scale should be above 0.70 , for most purposes, reliability coefficients higher than 0.70 are satisfactory, but coefficients in the 0.85 to 0.95 range are far preferable. On the other hand, Cronbach's alpha values are quite sensitive to the number of items in the scale. With short scales (e.g. scales with fewer that ten items), it is common to find relatively low Cronbach values (e.g. $0.5)$. In this study, the reliability test for the modified Kogan ATOP scale revealed a Cronbach's alpha score of 0.72 . Furthermore, the validity has been obtained through examination by a bilingual panel (Arabic and English) of 12 experts, recruited to establish the validity of the instruments. The panel consisted of experts in the fields of Gerontology, Geriatrics, Nursing, Medicine, Education and Research. It included faculty members from three universities and consultants from the Ministry of Health in Saudi Arabia. We sent a survey questionnaire to 173 nursing teachers to investigate their attitudes towards the care of older people, with a stamped addressed envelope for its return. Furthermore, a reminder was sent to the participants two weeks later. The questionnaire was filled in with complete anonymity and 
confidentiality in the nursing schools at three universities. Additionally, we explained the purpose of the study in a letter accompanying the questionnaire.

The focus group in this study was anticipated to play an important role in achieving the aim of this research, namely, to fill the gap and build bridges in nursing education in order to improve gerontology teaching. Focus groups were conducted with nursing teachers to explore the perceived status of gerontological nursing education in the undergraduate nursing curricula. The focus groups were held at the East University, Central University and West University. The participants in the focus groups comprised of nursing faculty members in three nursing schools at three universities in the Kingdom of Saudi Arabia. The main purpose was to discuss with them the status of gerontologic nursing education in the undergraduate nursing curricula in Saudi Arabia. A convenience sample was used for $t$ five focus groups in three nursing schools, with each group containing 6-8 members, including two teachers from each specialty: medical surgical nursing, fundamental nursing and community health nursing from East University, Central University and West University. Permission was obtained from the ethical committee at the school of Nursing and Midwifery. Furthermore, permission was sought from the three participating nursing schools. The Institutional Review Board at King Abdulaziz University approved the study protocol. Mixed groups with homogenous characteristics are usually preferable in focus group discussions ${ }^{(19)}$. The reason for selecting participants from various branches was because, in the nursing curriculum, integrated gerontology courses are mainly included in the above three specialties ${ }^{(19-20)}$.

Discussion with nursing teachers focused on their views and commitment toward teaching integrated gerontological nursing in undergraduate nursing curricula. Insights gained from exploring these perspectives would, hopefully, provide signposts for the teaching of gerontological nursing in nursing schools. This phase of the study involved focus group discussions, lasting one to one-anda-half hours, being conducted in meeting rooms at three major universities in the Kingdom of Saudi Arabia: Eastern University, Central University and Western University.

The focus group discussion, the moderator, should provide a short note to introduce the study and encourage the participants to participate actively. In the present study, five focus groups were held, one in each of the three nursing schools, with each group containing 6 to 8 members, including two teachers from each specialty: medical surgical nursing, fundamental nursing and community health nursing. Mixed groups with homogenous issues are usually preferable ${ }^{(19-20)}$. Likewise, that homogeneity in focus group allows more free-flowing conversations among participants within the group, which facilitates analysis that examines differences in perspective between groups $^{(21-23)}$. The reason for selecting participants from these three branches is because, in the nursing curriculum, integrated gerontology courses are mainly included in the above-named three specialties: fundamental nurs- ing, medical-surgical nursing and community health nursing. Permission was sought from nursing program Deans at the three nursing schools in the Kingdom of Arabia. We sent invitation letters with stamped addressed envelopes to nursing teachers from medical-surgical nursing, fundamental nursing and community health nursing specialties, asking them to share their thoughts on gerontology education. Nursing faculty members who agreed to participate of group discussions were able to return their reply slips with an envelope addressed to the investigator via the university post office system. We contacted the teachers to discuss the plan for the focus group, such as the time and place, and asked them to sign a consent form. The meeting rooms used were also convenient for teachers, as they were close to their offices and students' classrooms. We also provided more information about the study and clarified any questions about the study. The focus group discussions were conducted in meeting rooms in each nursing school, lasting one to one-and-a-half hours, and I provided refreshments for each sitting. Each focus group was recorded (with respondents' consent) so that all information was documented and could repeatedly be accessed during analysis. Additionally, the transcriptions of these focus group discussions were sent to participants, to achieve verification and adequate cross-referencing.

Focus groups discussion interview tapes were transcribed verbatim. There are three advantages to using tape transcripts in qualitative data: tapes can serve as a public record, can be replayed to improve the quality of transcripts and can preserve the sequence of the discussion ${ }^{(24)}$.

The steps taken to analyze the qualitative data are outlined below:

Step1: interview tapes were transcribed verbatim in Arabic by me and then entered into my computer. Each sentence was placed on a numbered line to help with sorting and coding.

Step 2: the transcripts of the Arabic version were translated into English by me for the publication purpose.

Step 3: the translations were sent to two Saudi nursing teachers to confirm the accuracy of the translation.

Step 4: the transcripts were read through several times and notes, and highlights were made throughout the reading.

Step 5: the transcripts were read through again, and several headings were categorized from the content. Open coding was used to derive categories from the text at this stage.

Step 6: The categories were grouped together, and I read and reread the results many times to look for similar categories for the purpose of data reduction.

Step 7: A list of headings was drawn up, and I ascertained the similarities between them; the final headings 
were grouped together to produce a set of results in the form of themes and categories.

Step 8: the transcripts were reviewed and separated into themes, and all instances of each theme were collected together. The theme section represents the display stage. Some themes were combined because they were very similar.

Step 9: the transcripts were read many times and subheadings were ascertained to identify repeated words and ensure that all aspects of the data were covered.

Step 10: to enhance the validity of the results, two Saudi nursing teachers checked the results and adjustments were made to the final results accordingly.

\section{RESULTS}

\section{Gerontology integration and academic preparation through the nursing program}

Table 1 illustrates that the majority of nursing faculty members (84.09\%: $n=111$ ) teach gerontology for nursing students through the nursing program as part of an integrated curriculum of medical, surgical, community health nursing, fundamental nursing and psychiatric nursing. Furthermore, the large majority of the faculty members $(n=122: 92.4 \%)$ had not received any academic gerontology nursing preparation. These results highlight the fact that nursing faculty staff teaching nursing students in the integrated gerontologic program at the Saudi BSN have not received graduate level preparation in this specialty, which leads to a lack of appropriate supervision by clinical preceptors who are adequately trained in gerontology and an absence of contact with gerontology professionals who might serve as positive career models in students' nursing future.

Table 1 - Integration of gerontology through nursing program and a academic preparation.

\begin{tabular}{lcc}
\hline Gerontology integration & Frequency & \% \\
\hline Gerontology teaching & 111 & 84.09 \\
Yes & 21 & 15.90 \\
No & & \\
Gerontology academic preparation & 2 & 1.5 \\
Doctorate in gerontology & 3 & 2.27 \\
Master's degree in gerontology & 5 & 3.7 \\
Other degree in gerontology & 122 & 92.4 \\
No preparation & $\mathbf{1 3 2}$ & $\mathbf{1 0 0 . 0}$ \\
\hline Total & & \\
\hline
\end{tabular}

\section{Curriculum plan for gerontology nursing at BSN programs}

Table 2 demonstrates that the majority of nursing teachers ( $n=109 ; 82.6 \%$ ) would prefer to include geron- tology as a standalone course in the nursing curriculum. This result highlights BSN teachers' suggestion to offer gerontological nursing as a separate course, with an emphasis on teaching gerontology theories and connected clinical issues related to older adults.

Table 2 - Curriculum plan to include gerontologic nursing as a standalone course in curriculum

\begin{tabular}{lcc}
\hline $\begin{array}{l}\text { Curriculum plan to include } \\
\text { gerontology as stand alone course }\end{array}$ & Frequency & $\boldsymbol{\%}$ \\
\hline Yes & 109 & 82.6 \\
No & 23 & 17.4 \\
\hline Total & $\mathbf{1 3 2}$ & $\mathbf{1 0 0 . 0}$ \\
\hline
\end{tabular}

\section{Factors that have the greatest influence on nursing students' choice of care of older adults as a future career choice}

Table 3 illustrates that BSN teachers $42 \%(n=56)$ agree that gerontology clinical experience as the greatest factor influencing nursing students' choice of care of older adults as a future career, followed by teaching methods of gerontologic nursing, which was cited as the main influence by $29 \%(n=38)$ of respondents. A further $17 \%(n=23)$ indicated that past experience with older people were the key determinants of their decision, while $7 \%(n=9)$ cited the nursing teachers as role models and $5 \%(n=6)$ indicated the effect of the peer group. The data reflect that clinical experience with older people had a great influence on nursing students' decisions regarding the care of older people as a future career.

Table 3-Factors that have the greatest influence on nursing students choice of care of older adults as a future career choice (one answer)

\begin{tabular}{lcc}
\hline $\begin{array}{l}\text { Factors that have the greatest influencing } \\
\text { nursing students' choice of older care as a } \\
\text { future career (one answer). }\end{array}$ & Frequency & \% \\
\hline Clinical experiences with older adults & 56 & 42.45 \\
Teaching methods of gerontologic nursing & 38 & 28.8 \\
Past experiences with older people & 23 & 17.4 \\
Nursing teachers as role models & 9 & 7 \\
Peer group & 6 & 4.54 \\
\hline Total & $\mathbf{1 3 2}$ & $\mathbf{1 0 0 . 0}$ \\
\hline
\end{tabular}

In this study, the analysis examines faculty members from three different nursing schools' attitudes towards older people $(n=132)$ and the relationship between these scores and their students' attitudes. The survey was given to 132 faculty members, including 76 clinical instructors, 40 associate professors and 16 professors. The modified Kogan Attitudes Toward Older People (ATOP) scale was used.

Table 4 shows that the nursing faculty in general had a positive attitude toward older people $(M=3.36$, SD 0.25) and teachers' attitudes were higher than those of their nursing students $(M=3.18$, SD0.29). The teachers were more mature and had attained higher levels of education than their students, which might have had a strong influence on their attitudes. An independent-samples t-test was performed to look for significant differences in attitudes between teachers and their students. 
Table 4 - Independent sample t- test between faculty members' attitudes and nursing students' attitudes toward care of older people

\begin{tabular}{|c|c|c|c|c|}
\hline Sample & $\mathbf{N}$ & Mean & $\begin{array}{c}\text { Std. } \\
\text { Deviation }\end{array}$ & P-value* Significance \\
\hline $\begin{array}{l}\text { Students attitudes } \\
\text { toward older } \\
\text { people }\end{array}$ & 566 & 3.18 & 0.29 & \multirow{3}{*}{$<0.001$} \\
\hline Teachers & & & & \\
\hline $\begin{array}{l}\text { Attitude toward } \\
\text { older people }\end{array}$ & 132 & 3.36 & 0.25 & \\
\hline
\end{tabular}

Furthermore, five focus groups, each comprising 6-8 nursing teachers from the nursing faculty, discussed the status of gerontologic education in nursing curricula.

Nursing students need to know how older people manifest disease symptoms differently than younger people, and that can improve their attitudes because they can understand them better in the clinical area with role model teachers (Group 2: NT5).

There are limited health services and resources available for older an person in Saudi Arabia, such as well-designed nursing homes, which makes it difficult for students to gain positive clinical experience with older individuals, and this might affect students' clinical experience and their attitudes towards elder care (Group 1: NT3)

When older people sought a relationship with nursing students, the students felt proud of the contact, but their period of education with older people is very short (Group 3: NT3).

A nursing curriculum with enough clinical experience in gerontologic nursing taught by qualified instructors who can serve as role models can make a change in older people's health services (Group 3: NT2).

Nursing students need role models who are highly qualified and skillful clinical instructors in gerontological nursing, but if schools provide a single course in gerontology, they will recruit more specialist staff who can help the students to learn in the correct way, and that that will strengthen the curriculum (Group 1: NT1).

Nursing students should have the opportunity to interact with the theoretical content of ageing in clinical experience to change their attitudes, and schools of nursing must provide expertise to help ensure that the curriculum is well prepared to improve the quality of nursing graduates' work with older people (Group 1: NT5).

\section{DISCUSSION}

The results of this study highlight the need for greater effort in the preparation of nursing students, with the provision of integrated skills and knowledge in the care of older people. These themes and categories deserve consideration in their right and should be focal concerns in the design of appropriate gerontologic nursing educational programs in Saudi Arabia. In light of this, several nursing teachers suggested that schools of nursing should include gerontology courses in their curricula and that they must be provided with positive clinical experience with both well and ill older people to encourage interest in this increasingly important specialization.

\section{Clinical training (experience)}

\section{A) Nursing students' attitudes}

The participants in the focus groups believed that positive clinical experiences with well and ill older people would increase students' self-confidence, and improve their attitudes towards work with older people.

\section{B) Nursing home experiences}

The teachers recognized that current clinical experience with older people in nursing homes in their training program was inadequate, with there being insufficient wellprepared nursing homes. This had a significant impact on nursing students' desire to work with older people.

\section{Students' teaching and learning experiences}

The groups argued that there was a need for wider use of experiential learning methods in the students program that promoted a relationship orientated rather than task oriented approach to care. In teaching the care of older people, they argued for the use of stories, diaries, reflective approaches and audiovisual materials.

With regard to experiential learning, the faculty teachers stressed that when nursing students visit older people in community settings and in long-term care facilities, it is very important to provide opportunities for them to develop personal relationships to improve their perceptions of older people. To achieve this, it was believed that students need to spend more time with older people; the teachers mentioned that some students feel proud when older people wish to establish relationships with them, but their contact time with older people is very limited.

\section{Teacher's role [mentors' and preceptors' role]}

In the focus group discussions, the nurse educators reflected that the BSN curriculum in gerontologic nursing will be strengthened when the nursing faculty members recognize the importance of teaching gerontologic nursing in the academic nursing program to improve older people's health services.

In a light of this, nursing faculty staff agreed that few of the nursing faculty members teaching nursing students on the Saudi BSN program in the three nursing schools under study were qualified gerontological nursing specialists. They reflected that the provision of gerontology as a separate course in the future would offer more specialist staff within the nursing colleges. Furthermore, these teachers will be able to work as role models in developing positive attitudes and focus their teaching efforts toward of the care of older patients, whether in theory or in clinical practice. 


\section{Curriculum}

The focus group participants asserted that the influence of education, early professional experience and the impact of professional knowledge were central to changing student nurses' attitudes toward older people and that gerontology education had a significant influence on positive attitudes that could lead to the acquisition of adequate knowledge to provide quality care for older people. In these data, there appears to be a gap between the educational needs of gerontological nursing and the current status of curricula and efforts needed to bridge the gaps between theory and practice in the Saudi nursing curriculum. In Saudi Arabia, nursing curricula have been designed to focus on theoretical contents and clinical experiences in specialty areas such as Medical-Surgical Nursing, Mental health, Community Nursing, Maternity and Pediatric Nursing. The focus has been on the young human in our society, with little, if any, emphasis being given to gerontological nursing content. The importance of education and training for nurses and other health care workers, caring older people, due to changing diseases and illness patterns in ever-widening health care institutions ${ }^{(25-26)}$.

However, from the points raised in this study, there appears to be a disparity between the educational needs of gerontological nursing and the current status of our curricula, because gerontological nursing as an educational specialty is considered new in Saudi Arabia. This disparity highlights a need for suitable places to practice clinical experience, such as nursing homes with ill and well older people, as well as specialist gerontological nurse educators with positive attitudes toward older people. All of these issues can be considered as challenges for academic nursing in Saudi Arabia. Geriatric nursing must be included in the nursing curriculum ${ }^{(27)}$. Alongside, the gerontology nursing concepts and theoretical arguments regarding older people to promote health, prevent diseases, give specific care, aid in the recovery and rehabilitation of older people and maintain their functional capacity.

In this study, the nurse educators who participated in the focus groups pointed out that nursing schools have not addressed this educational need in nursing curricula by providing appropriate clinical experience or role models or working to bridge the gaps between school and clinical placements in gerontological nursing. However, there are many positive and innovative approaches to educating and training nurses to work with older people and improving their awareness of older people's specific needs, biologically, psychologically, socially, spirituality and culturally, in the nursing curriculum. The nursing

\section{REFERENCES}

1. Palmore E. Response to "The factor structure of the Facts on Aging Quiz" [letter]. Gerontologist. 1988;28(1):125-6. schools need to build and design curriculum models in gerontology education and influence ageing knowledge ${ }^{(28)}$.

To meet these needs, it is vital to include gerontology nursing courses in the nursing curriculum of nursing schools as this study suggests. These gerontology courses, whether separate or integrated, are essential to bridge the gaps between theory and practice to improve students' knowledge and change their attitudes toward older people, thus encouraging them to select this type of work as a potential career choice ${ }^{(29)}$.

Furthermore, the development of an enriched program in teaching gerontology nursing is considered an important and vital issue in the Saudi nursing curriculum. In line with this, one study proposed that gerontology design models include assessment of multimedia presentations, learning activities, web-based assignments and case-study assessments and the content of the course should also expand from primarily clinical topics in geriatrics to include the social and emotional issues of ageing to motivate students and influence their attitudes and knowledge ${ }^{(30)}$.

In fact, the goal of nurse educators is to graduate nurses who have a broad knowledge base and the ability to meet the needs of their clients competently. I believe that nurse educators are committed, as a nursing faculty, to assisting the students to develop their capacity in the discipline of professional nursing, and that as professional nurses, they will recognize and respect older people.

\section{CONCLUSION}

This study's results are encouraging nursing educators to adjust the curriculum by adding gerontology content and appropriate clinical experiences to ensure that Saudi graduates are adequately prepared to take care of older people and have sufficient ageing knowledge. Therefore, nursing educators must evaluate their gerontology curricula regularly to identify any deficiencies and initiate the required changes as indicated in this study. I hope to use the knowledge gained from exploring these perspectives to inform baccalaureate nursing curriculum development in gerontology and implement comprehensive health care delivery for the ageing population. Health ministers, nursing educators, health care planners and administrators should work together to develop a gerontology program. And it should give more emphasis on clinical experiences with older people. That will promote the training of students in the care of older people and enhance their knowledge of ageing to encourage them to work with older people in a future.
2. Koren ME, Hertz J, Munroe D, Rossetti J, Robertson J, Plonczynski D, et al. Assessing students' learning needs and attitudes: considerations for gerontology curriculum planning. Gerontol Geriatr Educ. 2008;28(4):39-56. 
3. Wilkes L, LeMiere J. Caring for residents: the effects of education on staff attitude an knowledge in an aged care facility. Geriaction. 2001;19(3):15-21.

4. Morris AH. Factors influencing Bachelor of Science in Nursing students' perceptions of eldercare cultural self-efficacy [dissertation]. Auburn, Alabama: Auburn University; 2007.

5. Snyder C, Wesley S, Lin M, May JD. Bridging the gap: gerontology and social workeducation. Gerontol GeriatrEduc. 2008;28(4):1-21.

6. Briscoe VJ. The effects of gerontology nursing teaching methods on nursing student knowledge, attitudes, and desire to work with older adult clients [dissertation]. Minneapolis (MN): Walden University; 2004.

7. Miller S. Teachers' Topics. Theaching geriatrics to generation y. Am J Pharm Educ [Internet]. 2004 [cited 2014 June 13];68(3). Available from: http://archive.ajpe.org/aj6803/ aj680367/aj680367.pdf

8. Coffey A. The clinical learning portfolio: a practice development experience in gerontological nursing. J Clin Nurs. 2005;14(8b):75-83.

9. Brown D, Topcu M. Willingness to participate in clinical treatment research among older African Americans. Gerontologist. 2003;43(1):62-72.

10. Brown J. Student nurses experience of learning to care for older people in enriched environment: a constructivist inquiry [thesis]. Sheffield: University of Sheffield; 2006.

11. Brown J, Nolan M, Davies S. Bringing caring and competence into focus in gerontological nursing: a longitudinal, multimethod book. Int J Nurs Stud. 2008;45(5):654-67.

12. Brown J, Nolan M, Davies S, Nolan J, Keady J. Transforming students' views of gerontological nursing: realising the potential of 'enriched' environments of learning and care: a multi-method longitudinal book. Int J Nurs Stud. 2008;45(8):1214-32.

13. Hanson $\mathrm{H}$, Waters V. The sequence of curriculum change in gerontology: faculty first. Nurs Health Care. 1991;12(10):516-9.

14. Hughes $M$, Heycox $K$. Knowledge and interest in aging: a study of final-year social work students. Aust J Ageing. 2006;25(2):94-6.

15. Hughes NJ, Soiza RL, Chua M, Hoyle GE, MacDonald A, Primrose WR, et al. Medical student attitudes toward older people and willingness to consider a career in geriatric medicine. J Am Geriatr Soc. 2008;56(2):334-8.
16. Hweidi IM, Al-Hassan MA. Jordanian nurses' attitudes toward older patients in acute care settings. Int Nurs Rev. 2005;52(3):225-32.

17. Hweidi IM, Al-Obeisat SM. Jordanian nursing students' attitudes toward the elderly. Nurse Educ Today. 2006;26(1):23-30.

18. Jacelon CS. Attitudes and behaviors of hospital staff toward elders in an acute care setting. Appl Nurs Res. 2002;15(4):227-34.

19. Hek G. Asking the right question. In: Gerrish K, Lacey A. The research process in nursing. 5th ed. London: Blackwell; 2006. p.73-89.

20. Joyce P. Focus groups. In: Watson R, McKenna H, Cowman A, Keady J. Nursing research: designs and methods. Churchill Livingstone: Elsevier; 2008. p. 289-97.

21. Morgan DL. Why things (sometimes) go wrong in focus groups. Qual Health Res. 1995;5(4):516-23.

22. Morgan DL. Focus groups. Ann Rev Sociol.1996;22:129-52.

23. Morgan DL. Practical strategies for combining qualitative and quantitative methods: Applications to health research. Qual Health Res. 1998;8(3):362-76.

24. Silverman D. Interpreting qualitative data: methods for analyzing talk, text and interaction. 3rd ed. London: Sage; 2006.

25. Miles MB, Huberman AM. Qualitative data analysis: a sourcebook of new methods. 2nd ed. Newbury Park: Sage; 1994.

26. Andrews GJ, Brodie DA, Andrews JP, Wong J, Thomas BG. Place (ment) matters: Students' clinical experiences and their preferences for first employers. Int Nurs Rev. 2005;52(2):142-53.

27. Santos S. Enfermagem gerontólogica: reflexão sobre o processo de tabalho. Rev Gaucha Enferm. 2000;21(2):70-86.

28. Nolan M, Davies S, Brown J, Keady J, Nolan J. Beyond person-centred care: a new vision for gerontological nursing. J Clin Nurs. 2003;13(3a):45-53.

29. Rogan F, Wyllie A. Engaging undergraduate nursing students in the care of elderly residents in Australian nursing homes. Nurse Educ Pract. 2003;3(2):95-103.

30. Biein B. An older person as a subject of comprehensive geriatric approach. Rocz Akad Med Bialymst. 2005;50 Suppl 1:189-92.

\section{Acknowledgements}

This project was funded by the Deanship of Scientific Research (DSR), King Abdulaziz University, Jeddah. The authors, therefore, acknowledge with thanks DSR technical and financial support. 